having the shape and size of an orange, but resembling internally the American muruenia, that produces purgative effects when taken in large doses; the tongo, similar in form and dimensions to the white plum; and the tundo, almost equal to a cherry in taste, and having black seeds. The abundance of wax is really remarkable, and towards the south and south-east it constitutes an important branch of industry."

At this point the two travellers separated in order to proceed northwards on different sides of the Cuango, and met again at Cassange, where they fell in with Dr. Max Buchner, on his way to the great Muata Yanvo. Of this famous potentate Messrs. Capello and Ivens give a fancy portrait, which contrasts markedly with that taken from the original by the German explorers who have recently done so much for a scientific knowledge of the region through which the route of the Portuguese travellers lay. Cassange may be regarded as the furthest Portuguese outpost, and a busy centre it is.

Yacca, the furtheit limit of the expedition, was reached in May, I879, and although innumerable small lakes and many streams had been passed, the region beyond was found to be an arid desert, brooded over by "the silence of the grave." Here is a summary of the travellers' observations on the course of the Cuango from its source to the limit of their journey, about I 40 miles from where the river discharges into the Congo:-

"From parallel $1 \mathrm{I}^{\circ} 3 \mathrm{O}^{\circ}$, approximately, where its sources are to be found, up to $5^{\circ} 05^{\prime}$ at the Quicunji cascade, the river has a sinuous course of 580 geographic miles, and a total fall between its extreme points of about 3 feet 4 inches per mile. Rocks, stones, rapids, and cataracts interrupt the stream, and twelve of the points at which they do so are known to us, namely, the first at parallel $10^{\circ} 17^{\prime}$, to the east of Muene-songo; the second at $10^{\circ} 25^{\prime}$, near the Camba rivulet; the third at $10^{\circ} 08^{\prime}$, Caxita rocks; the fourth at $10^{\circ} 05^{\prime}$, the Louisa falls; the fifth at $10^{\circ} 05^{\prime}$, a cataract a little above Port Muhungo; the sixth at $9^{\circ} 20^{\prime}$, Zamba ; the seventh at I9 $9^{\circ} 9^{\prime}$, Tuaza; the eighth at $9^{\circ}$, cataract Cunga-riaCunga; the ninth at $7^{\circ} 42^{\prime}$, Suco-ia-Muquita or Suco-ian'bundi; the tenth at $7^{\circ} 38^{\prime}$, just below the Camba; the eleventh at $7^{\circ} 35^{\prime}$, in the midst of numerous islands; and the twelfth at $5^{\circ} 05^{\prime}$, the Quicunji waterfall, which is only passable after the heavy rains. The greatest navigable tract, therefore, is that space which lies between the cataract at $7^{\circ} 35^{\prime}$ and Quicunji, or about 190 geographic miles. The river there is of variable width, never less than $76 \frac{1}{2}$ yards, and from 5 to 20 feet in depth. The current loses a little of its speed in the upper section, where the stream in the summer season has a fall of about 3 feet 2 inches per mile. We think it well to mention that our longitudes being strictly correct, as the record, partly chronometric, was compared both on departure and arrival at the Portuguese station of Duque de Bragança, and the latter again at the terminus on the coast, it appears to us that the point of affluence of the Cuango (or Ibari-N'Kutu) as marked upon the maps, just above Stanley Pool, is erroneously placed considerably to the eastward."

Major von Mechow, who has been exploring the river urther down its course, has found it equally unnavigable, and we may say that the maps illustrating Mr. Stanley's last journey to the Congo place the mouth of the river further west than on those of his famous trans-African expedition. It was this river which $\mathrm{Mr}$. Stanley as. cended in his little steamer, and found it expanding into a broad lake. Messrs. Capello and Ivens came to the conclusion, confirmed by Major von Mechow, that no such lake as Aquilonda exists in this quarter. The travellers returned by a somewhat different route, staying for some time at Pungo N'Dongo, with its famous rocks, and reaching Loanda in October, 1879.

The work abounds with illustrations of the country and the people, many of them devoted to natural history. On the animal and plant life of the district traversed there are many valuable notes, and in the appendix will be found, besides tables of geographical observations anheights above sea-level, lists of additions to the fauna and flora, tables of African dialects, and a N'Bunda Vocabulary. There is a good summary of the general results in the concluding chapter, in which the authors have the following observations on the geology of the continent:-

"The physical configuration of the African continent, and more especially of the portion south of the equator, is nowadays too well known to require minute description. It may be summed up in these few words: a depressed central basin surrounded by a vast circle of high land, gradually descending to the sea, and rent by deep ravines, through which rush huge watercourses, engendered in the interior, till they overflow and seek the lower level fronting the ocean. From a very general geological point of view we may define the regions running from the littoral to the interior in the following order, viz. limestone, sandstone, and granite. But on going more minutely into the subject we shall find that these distinctions are not very exact; inasmuch as the component parts frequently run into each other and change places, while precise lines of demarcation are wanting. The geological formation on the western coast at the points observed by us between Loanda and Mossamedes, and even further to the north, exhibits generally near the sea a belt of tertiary deposits, with abundant masses of sulphate of lime and sandstone, from which they are separated by beds of white chalk alternating with primary rocks, for the most part gneiss, abounding in quartz, mica, hornblende, granite, and granulated porphyry. Towards the south large tracts of feldspar become visible. At Mossamedes whole mountains are composed of sulphate of lime; while carbonate of lime, accumulated in shells, is very frequent. Both rock-salt and nitrate of potash are found in stratification. Along the Mocambe chain, we were informed, there exists a basaltic line of great length. From that point the shifting soil may be said to commence, extremely abundant in sand, constituting true saharas, as in the parallel of Tiger Bay. In the transition from the lower zone towards the interior, for instance at Dondo, vast tracts of schist rock, in perfect laminæ, compose the soil; and sandstone reddened by oxide of iron, is visible in every direction. Proceeding further into the interior we find, in a perfectly mountainous region, the ground to be composed of granite-quartzy rock, extremely hard and compact; this is the case throughout the belt crossed on the way and up to Pungo N'Dongo, the surface soil being formed by the disintegration of the granite itself. These geological characteristics will naturally be repeated to the south and north in identical parallel regions, with variations in the high table-land, where we meet occasionally with hard and tough red sandstone and rock; of feldspar as in the basin of the Lucalla."

In the same chapter will be found abundant notes on the various tribes visited, which, although the authors' ethnology appears to us by no means sound, are still a valuable contribution to a knowledge of the African peoples. As evidence of the important contributions to the natural history of West Africa, we give a few of the illustrations bearing on the subject.

\section{ON THE AURORA BOREALIS}

HAVING been requested by this journal to give an account of my latest researches into the nature of the aurora borealis, I must explain that my lateness in

I In reference to the present interesting communication from Herr Sophus Tromholt, from his station in Ultima Thule, we ought to point out that Herr as regards the nature of the aurJra made by Prof. Lemström at the Finnish station of Sodankylä during December appeared in NATURE, vol. xxvii. p. $3^{22}$. 
complying with this request arises from the fact that I had this winter changed my residence from Bergen, where the communication was directed, to this spotKautokeino, in Ultima Thule.

Since September last I have, for the sake of the aurora borealis, been residing here in North Finmarken $\left(69^{\circ} \mathrm{N}\right.$. lat., $23^{\circ} \mathrm{E}$. long $)$, in a quarter, therefore, where the auroræ attain their maxima, and where the phenomena, consequently, are so frequent and on such a scale that there cannot be a question of selecting and analysing one in particular. I therefore prefer to give briefly a description of its general appearance here, its character and occurrence.

My winter sojourn here has two objects in view-viz. firstly, to frame a pendant to the observations of the auroræ made at Bossekop, $1838-39$, by the French Commission du Nord ("Voyages en Scandinavie," \&c.), which, by the bye, later students of the phenomenon seem to have entirely ignored; and secondly, by means of altitudinal measurements corresponding with those now being made at the Norwegian Meteorological Station at Bossekop, to procure sufficient materials for fixing the parallax of the aurora borealis. I choose the remote Kautokeino for my observatory for several reasons-viz. that this place is situated almost exactly south of Bossekop, while the distance between the two places is very nearly a degree, a distance which is exactly suited to the opinion I have formed as to the height of the aurora, viz. I50 kilometres, and also for the reason that Kautokeino possesses a very free horizon, and that its situation, very far inland, would insure favourable weather conditions.

As previously stated, observations are made simultaneously here and at Bossekop on a common prearranged plan, and measurements made in the common vertical plane by the so-called auroral theodolite, constructed by Prof. Mohn. A similar arrangement has also been effected with the Finnish Meteorological Station at Sodankylä, which is, however, situated at a great distance from this place and in a somewhat unfavourable direction (about $45^{\circ}$ S.E.). We shall not, of course, be able to compare notes before the spring, so I am unable at present to lay before the reader the final results; but judging from my own researches here, I feel convinced, in spite of assertions made by scientists to the contrary, that the exact height of the aurora may be ascertained by the method I advocate, and that from the observations made at these three stations we shall glean sufficient materials to solve a problem hitherto deemed an insoluble one.

Auroræ occur here, I may say without exaggeration, every night, and an evening without them would be a phenomenon as remarkable as their appearance under the equator. Unfortunately, however, unfavourable weather has during the last two months, accompanied by cloud masses unusual in these latitudes, sadly interfered with the number and completeness of my observations. Still, the magnitude of the auroræ is not the same every night. Sometimes they appear as short, faint, arc-shaped phenomena, similar to those so frequently seen in South Norway, while at others they assume an extent and grandeur which mocks every attempt at description.

In one respect my researches here have been of great moment to me, i.e. with regard to understanding the various types of the auroræ, their real strike and shafe, and their exterior appearance, which changes in the different altitudes above the horizon; while on account of their frequency, and the circumstance that they now appear in the north, then in the south, and at last in zenith, there is a splendid opportunity to study the modifications which one particular form of aurora is subjected to when changing its position to the observer. It appears now conclusive to me that the many forms usually described in researches may be reduced to a few, almost similar, types. In most instances the aurora runs in zones, belts, in the direction of the magnetic east-west, and either as a more or less diffuse luminosity, or as thin shining bands, which I have found to be parallel with the indication of the inclination needle. But the appearance which the phenomenon assumes is entirely dependent on the relative position which the observer occupies to the same. If he is thus greatly distanced from the aurora he will only observe, a few degrees above the horizon, a continuous arc with streamers, but if he approaches nearer, he will notice several such arcs with clearly defined constituents and a greater vibratory motion, and if still closer, he will see the "belts" or bands mentioned by Weyprecht far above the horizon; and if these then travel towards his zenith, he will distinctly see the auroral " corona." I have just stated that the main strike of the auroræ is magnetic east-west; this is, however, only stated as a general rule, particularly with those of the luminous or "glory" type, while the "belts" may, besides their slight folds, be twisted and slung in almost any direction. I have thus seen them stretch from north to south, and even form a continuous circle, which, with zenith as centrum, has engirdled the entire heavens at an elevation of about $30^{\circ}$. The variable position of these luminous belts is the cause of the many peculiarities and the deviations from the normal which are so frequently observed with the arcs, as, for instance, their unsymmetrical position in relation to the magnetic meridian, and their uneven shape, viz. that they are often bent ecliptically back at the points, or even take the appearance of regular eclipses. I ought, however, to point out that the faint retrograding bend which great arcs assume near the horizon is due simply to optical causes. The study of the auroral corona here is very instructive. When a belt of streamers travels towards the magnetic zenith, the radiations seem to become shorter and shorter, caused by the circumstance that they are seen obliquely, and when the belt passes the magnetic zenith, its lower rim only is seen, which makes it appear as a bent and folded luminous belt. In this position one may observe that every individual streamer has only a very limited depth, but that the belt consists of several, sometimes of a great number, of luminous "sheets" in a parallel position to one another.

Besides this form of aurora, which thus embraces two kinds, viz. the continuous and the radiating, I know only one more of a character distinctly differing from the same. I do not thus consider the individual knots of rayauroræ, or the streamers, as anything but incomplete belts; while the luminous gatherings I consider are merely remnants, so to say, of previously radiant auroræ. I may also here state that the large purple auroral clouds peculiar to this phenomenon, when observed during considerable electrical disturbances in southern climes, I have never seen at Kautokeino.

Of quite a different nature is, however, the phenomenon which I have named "coruscation." This phase of the aurora, which almost without exception belongs to the earliest hours of the morning, and after large and extended oscillations of the aurora, is developed, I believe, by the luminous clouds. But while these remain quiet, or show at least subdued oscillations, the "coruscation," as I term it, is so violent and of such a peculiar nature, that I have not even yet succeeded in ascertaining whether the motion is horizontal or vertical, or whether it is the luminous clouds themselves which flood the heavens, or their merely momentary "blazing up" under the influence of some passing waves of energy. The entire heaven is sometimes for hours a bath of liquid fire by this force, which seems, by the bye, to possess the same remarkable rapidity around zenith as at lower elevations.

As regard the colours of the auroræ, I have only noticed, when the substance of light is great, and when the oscillations are very rapid, two well-known forms, viz. green 
and red. These are, however, only seen in the arcs as their lower rim, and by the forward movement one part assumes a red, another a green tint. The red colour sometimes changes into violet or ochre.

The spectroscope I have not had much opportunity of using here, but the well-known auroral "line" I can always see; any others I have not observed.

With regard to the height of the aurora I have, judging from observation, come to the conclusion that it does not appear at a lower elevation here than it does in the south of Norway, while I am convinced that its plane is to be found far above that of the clouds. There has often enough been an opportunity of observing auroræ and clouds simultaneously, but never has there been the slightest indication of the auroræ having descended to the sphere of the clouds, not even under the most violent oscillations and the most intense luminosity and play of colour. In fact I have come to the conclusion that the auroræ which I have watched at Kautokeino are identical with those I have studied in southern latitudes, while their plane is at the elevation which I estimated when choosing Kautokeino as my station of observation.

I may in conclusion state that I have never myself heard the slightest approach to any auroral "noise," and this in spite of my most earnest attention to this somuch-disputed question. Still if I ask the native people (Lapps) about here as to the "noise" there is not a single one who doubts its existence, while several even assert that they have heard it.

I have several times attempted to photograph the aurora borealis, but without success. Thus even by using the most sensitive English "dry" plates, and exposing them from five to seven minutes, I have not obtained a trace of a negative. The cause of this is, I believe, the exceedingly limited substance of light possessed by the auroræ: were thus even the entire heavens flooded by the most intense auroræ, their aggregate lighting capacity would not equal that of the moon when full. I may therefore assume that photographing the aurora borealis is an impossibility.

Kautokeino, Finmarken, Norway, January 28

\section{PROFESSOR HUXLEY ON FDUCATION}

$\mathrm{N}$ the 16 th inst., Prof. Huxley gave an address in connection with the distribution of prizes at the Liverpool Institute, a revised report of which will appear in the next number of the Journal of Education. By the courtesy of the editor of that journal, we are enabled to give a few extracts from Professor Huxley's address. He began by referring to certain propositions which he laid down in the address he gave in Liverpool fourteen years ago as to the practical value of instruction in physical science, its superiority to any other study as a mental discipline, and the certainty that in the future physical science would occupy a much larger share in the time allotted to teaching than had been the case previously. He also laid special stress upon the fact that he was no advocate of the exclusion of other forms of culture from education, but, on the contrary, insisted that it would be a serious mistake to cripple them for the sake of science. He had no sympathy, he said, with a kind of sect or horde of scientific Goths or Vandals who think that it would be proper and desirable to sweep away all other forms of culture and instruction except those in physical science. After referring to the great variety of his past experiences, his familiarity with every form of society, from the uncivilised savage of Papua and Australia, to the occasionally somewhat over-civilised members of our upper ten thousand, and to his interest in every branch of knowledge and form of art, Prof. Huxley insisted on the vast importance of science in education, when properly taught.
He pointed out, however, that unless the knowledge conveyed in the teaching of science or in the teaching of history were actually realised to themselves by the learners, it would be worse than useless.

"Make it as little as you like, but unless that which is taught is based on actual observation and familiarity with facts it is better left alone. There are a great many people who imagine that elementary teaching might be properly carried out by teachers provided with only elementary knowledge. Let me assure you that that is the profoundest mistake in the world. There is nothing so difficult to do as to write a good elementary book, and there is nobody so hard to teach properly and well as people who know nothing about a subject; and I will tell you why. If I address an audience of persons who are occupied in the same line of work as myself I can assume that they know a vast deal, and that they can find out the blunders I make. If they don't, it is their fault and not mine; but when I appear before a body of people who know nothing about the matter, who take for gospel whatever I say, surely it becomes needful that I consider what I say, make sure that it will bear examination, and that I do not impose upon the credulity of those who have faith in me. In the second place, it involves that difficult process of knowing what you know so well that you can talk about it as you can talk about your ordinary business. A man can always talk about his own business. $\mathrm{He}$ can always make it plain; but if his knowledge is hearsay he is afraid to go beyond what he has recollected and put it before those that are ignorant in such a shape that they shall comprehend it. That is why, to be a good elementary teacher, to teach the elements of any subject, requires most careful consideration if you are a master of the subject ; and if you are not a master of it it is needful you should familiarise yourself with so much as you are called upon to teach-soak yourself in it, so to speakuntil you know it as part of your daily life and daily knowledge, and then you will be able to teach anybody. That is what I mean by practical teachers, and although the deficiency is being remedied to a large extent, I think it is one which has long existed, and which has existed from no fault of those who undertook to teach, but because until within the last score years it absolutely was not possible for any one in a great many branches of science, whatever his desire might be, to get instruction which would enable him to be a good teacher of elementary things. All that is being rapidly altered, and I hope it will soon become a thing of the past."

Then as to the important question of time, Prof. Huxley said that all he asked for was that scientific teaching should be put into what politicians and statesmen call the condition of the "most favoured nation"; that is to say, that it shall have as large a share of the time given to education as any other principal subject. On the important question as to what should be regarded as "principal subjects," Prof. Huxley remarked as follows :-

"I take it that the whole object of education is, in the first place, to train the faculties of the young in such a manner as to give their possessors the best chance of being happy and useful in their generation; and, in the second place, to furnish them with the most important portions of that immense capitalised experience of the human race which we call knowledge of various kinds. I am using the term knowledge in its widest possible sense, and the question is what subjects to select, by training and discipline in which the object I have just defined may be best attained. I must call your attention further to this fact, that all the subjects of our thoughts, feelings, and propositions, leaving aside the mere materials and occasions of thinking and feeling-our sensations as all our mental furniture - may be classified under one of two heads : as either within the province of the intellect, something that can be put into proposition and affirmed or denied, 